\title{
Needle stick unjuries among health care workers - a report from India
}

\author{
D Sureshkumar ${ }^{*}, V$ Ramasubramanian, K Abdulghafur \\ From International Conference on Prevention \& Infection Control (ICPIC 2011) \\ Geneva, Switzerland. 29 June - 2 July 2011
}

\section{Introduction / objectives}

Preventing needle stick injuries (NSIs) is a challenge faced in virtually every work environment. There are very few studies in India documenting frequencies and consequences of needle stick injuries (NSIs). We report a 30 months ongoing surveillance of NSIs happened in Apollo Hospitals, Chennai (large tertiary care hospital in India).

\section{Methods}

Hospital infection control team document type of NSI, human immunodeficiency virus(HIV), Hepatitis B surface antigen (HBsAg, and hepatitis $\mathrm{C}$ virus (HCV) status of the source, anti HBs antibody titers of $\mathrm{HCW}$, baseline and 6 months tests for HIV if the source was positive for HIV, and provided post-exposure prophylaxis to persons who had NSI.

\section{Results}

Of the 118 needle stick injuries reported during the surveillance period $47(40 \%)$ were nurses, $25(21 \%)$ were lab technicians, 24 (20\%) were doctors, 20 (17\%) were housekeeping staff and 2(2\%) were other staffs. Hollow bore needle constituted $80.1 \%$ (95) of the injuries, solid needles constituted 16.5\% (19) of the injuries and other sharps constituted $3.4 \%$ (4) of the injuries. On source analysis 17, 9, and 8 were positive for HBsAg, HIV and $\mathrm{HCV}$, respectively. Improper disposal of the needles (27\%) \& recapping of the needle $(25.8 \%)$ were the predominant activities responsible for NSIs. 9 HCWs who sustained injury with HIV positive source were given immediate antiretroviral therapy for 4 weeks. Subsequent six-month follow-up showed zero seroconversion.

Infectious disease, Apollo Hospitals, Chennai, India

\section{Conclusion}

NSIs were common among nurses \& lab technicians and commonly take place in ICU. Half of the NSIs were happened after the usage of the needle before its disposal. Zero sero conversion for HIV was seen in NSIs with HIV positive source. Safer disposing methods are needed to reduce the incidence of NSIs.

\section{Disclosure of interest}

None declared.

Published: 29 June 2011

doi:10.1186/1753-6561-5-S6-P225

Cite this article as: Sureshkumar et al:: Needle stick unjuries among

health care workers - a report from India. BMC Proceedings 2011 5(Suppl 6):P225.
Submit your next manuscript to BioMed Central and take full advantage of:

- Convenient online submission

- Thorough peer review

- No space constraints or color figure charges

- Immediate publication on acceptance

- Inclusion in PubMed, CAS, Scopus and Google Scholar

- Research which is freely available for redistribution
C Biomed Central

\section{Biomed Central}

